\title{
Mucociliary clearance during and after isocapnic hyperventilation with dry air in the presence of frusemide
}

\author{
E. Daviskas*, S.D. Anderson*, I. Gonda+, D. Bailey**, G. Bautovich**, J.P. Seale ${ }^{++}$
}

Mucociliary clearance during and after isocapnic hyperventilation with dry air in the presence of frusemide. E. Daviskas, S.D. Anderson, I. Gonda, D. Bailey, G. Bautovich, J.P. Seale. @ERS Journals Ltd 1996.

ABSTRACT: We have previously shown that mucociliary clearance (MCC) decreased during and increased after isocapnic hyperventilation (ISH) with dry air, both in asthmatic and healthy subjects. Inhaled frusemide, an inhibitor of the $\mathrm{Na}^{+} / \mathrm{K}^{+} / 2 \mathrm{Cl}$ and $\mathrm{NaCl}$ co-transporters on the basolateral membrane of the epithelial cell, prevents the airway narrowing provoked by ISH with dry air. The co-transport system controls epithelial cell volume and chloride secretion and, thus, frusemide has the potential to modify the rate of recovery of periciliary fluid volume during and after ISH with dry air, and hence affect MCC. Frusemide also blocks mediator release from mast cells, which may also modify the increase in MCC after ISH.

Eleven asthmatic and 11 healthy subjects inhaled frusemide $(35.7 \pm 0.44 \mathrm{mg})$ or its vehicle, from a Fisoneb ${ }^{\mathrm{TM}}$ ultrasonic nebulizer $30 \mathrm{~min}$ before ISH with dry air, on two separate occasions. MCC was measured using ${ }^{99 m T c}$-sulphur colloid and a gamma camera. Frusemide, compared to its vehicle, did not affect MCC during or $45 \mathrm{~min}$ after ISH. However, in the presence of frusemide, the onset of the increase of MCC after ISH was significantly delayed for approximately $10 \mathrm{~min}$ in the whole right lung $(p<0.002)$ and central region $(p<0.01)$ in the asthmatic but not in the healthy subjects.

These findings could be explained by frusemide delaying the recovery of the periciliary fluid volume after ISH with dry air and/or interfering with the stimulus that causes the increase in MCC in the asthmatic subjects after ISH. Eur Respir J., 1996, 9, 716-724.
Depts of *Respiratory Medicine \& **Nuclear Medicine, Royal Prince Alfred Hospital, Sydney, Australia. +Genentech Inc., South San Francisco, CA, USA. ++Dept of Pharmacology, University of Sydney, Sydney, Australia.

Correspondence: S.D Anderson

Department of Respiratory Medicine

PCP Level 9

Royal Prince Alfred Hospital

Missenden Rd

Camperdown

NSW 2050

Australia

Keywords: Asthma

frusemide

hyperventilation

mucociliary clearance

Received: May 121995

Accepted after revision November 231995

This study was supported, in part, by a grant from the Asthma Foundation of New South Wales and the National Health and Medical Research Council of Australia.
Isocapnic hyperventilation (ISH) with dry air results in significant water loss from the airways whilst bringing the inspired air to alveolar conditions. The water loss from the airways is the stimulus whereby hyperpnoea provokes airway narrowing $[1,2]$. Mucociliary clearance (MCC) decreases during and increases after ISH with dry air, compared to ISH with warm humid air and nasal breathing at rest [3]. The effect of ISH with dry air on MCC is most likely to be due to a reduction of the depth of the periciliary fluid layer, with the subsequent hyperosmolarity leading to release of mediators [4]. Frusemide, a loop diuretic known to inhibit the $\mathrm{Na}^{+} / \mathrm{K}^{+} / 2 \mathrm{Cl}^{-}$and $\mathrm{NaCl}$ co-transport systems at the basolateral membrane [5], inhibits the airway narrowing induced by exercise [6], ISH [7, 8], and hypertonic saline [9]. Inhibition of the co-transport systems affects the regulatory volume increase (RVI) of the hypertonically shrunken epithelial cells [10], and chloride secretion [5]. Therefore, frusemide has the potential to interfere with the water availability to the periciliary fluid layer.

The mechanism by which frusemide protects against dry air and hyperosmolar challenges in asthma is not clearly understood. It is possible that it interferes with the transport of the chloride ion or the chloride channel under stimulatory conditions and, thereby, blocks mediator release from mast cells [11], which are located in the airway lumen or epithelium.

We decided to investigate the effect of frusemide on MCC during and after ISH with dry air because of its potential to affect the water transport to the airways, when the water demand is high. We also wished to further our knowledge of the mechanism whereby frusemide inhibits airway narrowing.

\section{Material and methods}

The study was approved by the Ethics Review Committee of Central Sydney Area Health Service and informed consent was obtained in writing from all subjects before participating in the studies.

\section{Subjects}

Eleven asthmatic and 11 healthy volunteers took part in the study. Their characteristics are given in table 1 . The asthmatic subjects had stable asthma and a resting forced expiratory volume in one second (FEV1) $>85 \%$ of predicted with the exception of subject No. 5 (table 1). 
Table 1. - Anthropometric data, baseline lung function, ventilation rate (\% maximum voluntary ventilation (MVV)) duration of isocapnic hyperventilation (ISH), responses to ISH with dry air of asthmatic and healthy subjects and medications taken by the asthmatic subjects

\begin{tabular}{|c|c|c|c|c|c|c|c|c|c|c|c|c|}
\hline \multirow{2}{*}{ No. } & \multirow{2}{*}{$\begin{array}{l}\text { Age } \\
\text { yrs }\end{array}$} & \multirow{2}{*}{ Sex } & \multirow{2}{*}{$\begin{array}{c}\text { Height } \\
\mathrm{cm}\end{array}$} & \multirow{2}{*}{$\begin{array}{l}\text { Baseline } \\
\text { FEV1 } \\
\% \text { pred }\end{array}$} & \multicolumn{3}{|c|}{ Ventilation } & \multirow{2}{*}{$\begin{array}{c}\text { Fall FEV1 } \\
\text { Dry ISH } \\
\%\end{array}$} & \multirow[t]{2}{*}{ Atopy } & \multicolumn{3}{|c|}{ Medication } \\
\hline & & & & & $\mathrm{L} \cdot \mathrm{min}^{-1}$ & $\% \mathrm{MVV}$ & $\begin{array}{l}\text { Duration } \\
\text { min }\end{array}$ & & & Drug & $\begin{array}{c}\text { Steroid } \\
\text { dose } \mu \mathrm{g}\end{array}$ & $\begin{array}{l}\text { Time on } \\
\text { months }\end{array}$ \\
\hline \multicolumn{13}{|c|}{ Asthmatic subjects } \\
\hline 1 & 23 & M & 176 & 94 & 90 & 59 & 8 & 20 & Y & $\mathrm{S}, \mathrm{BEC}$ & 1000 & 18 \\
\hline 2 & 21 & M & 189 & 95 & 104 & 57 & 8 & 16 & $\mathrm{Y}$ & NIL & & \\
\hline 3 & 20 & $\mathrm{M}$ & 182 & 102 & 94 & 56 & 6 & 18 & $\mathrm{Y}$ & S,BUD & 400 & 1 \\
\hline 4 & 21 & M & 168 & 98 & 87 & 61 & 8 & 9 & $\mathrm{Y}$ & S,BUD & 400 & 4 \\
\hline 5 & 24 & $\mathrm{M}$ & 171 & 74 & 86 & 60 & 6 & 4 & $\mathrm{Y}$ & S,BUD & 1000 & 1.5 \\
\hline 6 & 28 & M & 182 & 96 & 97 & 60 & 8 & 23 & $\mathrm{Y}$ & NIL & & \\
\hline 7 & 31 & M & 174 & 111 & 87 & 60 & 8 & 13 & $\mathrm{Y}$ & NIL & & \\
\hline 8 & 28 & M & 168 & 91 & 74 & 54 & 6 & 18 & $\mathrm{Y}$ & S,BUD & 1600 & 4 \\
\hline 9 & 19 & M & 174 & 86 & 95 & 61 & 8 & 12 & $\mathrm{~N}$ & $\mathrm{~S}$ & & \\
\hline 10 & 20 & M & 163 & 99 & 85 & 63 & 6 & 22 & Y & S,BUD,SCG & 800 & 2 \\
\hline 11 & 24 & $\mathrm{~F}$ & 163 & 157 & 64 & 59 & 8 & 10 & $\mathrm{Y}$ & T,BUD & 1200 & 52 \\
\hline Mean & 24 & & 174 & 100 & 90 & & & 15 & & & & \\
\hline$\pm \mathrm{SD}$ & 4 & & 8 & 21 & 8 & & & 6 & & & & \\
\hline \multicolumn{13}{|c|}{ Healthy subjects } \\
\hline 12 & 39 & $\mathrm{M}$ & 173 & 100 & 90 & 52 & 8 & 3 & $\mathrm{Y}$ & - & - & - \\
\hline 13 & 20 & M & 184 & 107 & 103 & 60 & 8 & 5 & $\mathrm{Y}$ & - & - & - \\
\hline 14 & 19 & M & 184 & 96 & 100 & 58 & 8 & 3 & $\mathrm{Y}$ & - & - & - \\
\hline 15 & 23 & $\mathrm{M}$ & 178 & 115 & 96 & 61 & 8 & 0 & $\mathrm{~N}$ & - & - & - \\
\hline 16 & 37 & M & 180 & 102 & 85 & 56 & 8 & 2 & $\mathrm{~N}$ & - & - & - \\
\hline 17 & 23 & M & 176 & 103 & 93 & 60 & 8 & 2 & $\mathrm{Y}$ & - & - & - \\
\hline 18 & 33 & M & 192 & 146 & 127 & 72 & 8 & 3 & $\mathrm{~N}$ & - & - & - \\
\hline 19 & 21 & M & 172 & 107 & 94 & 63 & 8 & 5 & $\mathrm{~N}$ & - & - & - \\
\hline 20 & 41 & $\mathrm{~F}$ & 168 & 118 & 80 & 59 & 8 & 2 & $\mathrm{~N}$ & - & - & - \\
\hline 21 & 23 & $\mathrm{~F}$ & 162 & 112 & 60 & 55 & 8 & 0 & $\mathrm{~N}$ & - & - & - \\
\hline 22 & 25 & $\mathrm{~F}$ & 166 & 133 & 67 & 59 & 8 & 0 & $\mathrm{~N}$ & - & - & - \\
\hline Mean & 28 & & 176 & 113 & 90 & & & 2 & & & & \\
\hline$\pm \mathrm{SD}$ & 8 & & 9 & 15 & 18 & & & 2 & & & & \\
\hline
\end{tabular}

M: male; F: female; FEV1: forced expiratory volume in one second; Y: yes; N: no; BEC: beclamethasone; BUD: budesonide; S: salbutamol; SCG: sodium cromoglycate; T: terbutaline.

Most of the asthmatics were on inhaled beta-agonists daily or as needed, and on inhaled corticosteroid medication (either beclomethasone or budesonide). All asthmatics withheld their medications for at least $8 \mathrm{~h}$. No asthmatic subject was taking theophylline. All subjects were asked not to take any nonsteroidal anti-inflammatory drugs for at least $48 \mathrm{~h}$ prior to each study day. The subjects did not have a history of smoking. They did not have a lower respiratory tract infection in the 6 weeks prior to each study.

\section{Study design}

The study involved three visits. All subjects had their lung function measured before and after ISH with dry air, prior to mucociliary clearance study days (Visit 1). MCC was measured on visits 2 and 3 , and the procedure on each day was as follows: 1) spirometry; 2) inhalation of frusemide or its vehicle for about $7 \mathrm{~min}$; 3) radioaerosol inhalation; 4) emission anterior/posterior gamma camera images (static) to obtain initial dose in the lung; 5) ISH for 6-8 min; and 6) emission anterior/posterior gamma camera images (dynamic) for $45 \mathrm{~min}$.
The order of MCC studies involving frusemide or its vehicle was random.

\section{Measurement of lung function}

Spirometry, using a hot wire anemometer (Minato, AS500, Osaka, Japan), was measured before and after ISH challenge with dry air, on the first visit. All subjects had normal and reproducible spirometry at rest. Subjects were included in the study if they had a spontaneous recovery within $30 \mathrm{~min}$ after the challenge and they were not distressed by the induction of asthma. To avoid possible changes in mucociliary clearance with the forced manoeuvres, lung function after ISH was not measured on the mucociliary clearance study days. The airway responses after ISH, in the presence of frusemide, were not measured. In all studies, predicted values for lung volumes were taken from GoLDMAN and BECKLAKE [12] for adults.

\section{Delivery of frusemide and its vehicle}

Ampoules of frusemide (Lasix; Hoechst, Germany) each containing $20 \mathrm{mg}$ frusemide in $2 \mathrm{~mL}$ ( $\mathrm{pH} \mathrm{9,} \mathrm{osmolarity}$ 
303 mosm) were used in this study. The vehicle was $0.9 \%$ saline adjusted to $\mathrm{pH} 9$ by adding $0.1 \mathrm{M}$ sodium hydroxide, prior to delivery. A pH meter (Radiometer PHM 62; Copenhagen, Denmark) was used to measure the $\mathrm{pH}$ of frusemide and its vehicle. Frusemide or its vehicle was delivered as an aerosol via a Fisoneb TM ultrasonic nebulizer (Fisons, Rochester, New York, USA) which produces a dense aerosol with a mass median aerodynamic diameter of $4.7 \mu \mathrm{m}$. Six millilitres of frusemide were placed in the Fisoneb $\overparen{T M}$ and inhaled for about 7 min. The subject inhaled the aerosol through a mouthpiece, at a resting rate of breathing, while wearing a noseclip. The nebulizer was weighed (Sartorius Analytic, Gottingen, Germany) before and after nebulization with a stopper placed in the output hole to reduce loss of volume by evaporation. The difference in weight was recorded as the amount that was nebulized. Approximately $35.7 \pm 0.44 \mathrm{mg}$ of frusemide was nebulized.

\section{Isocapnic hyperventilation}

The technique used was similar to the one described by Phillips et al. [13]. Dry compressed air containing $21 \%$ oxygen, $4.9 \%$ carbon dioxide, and nitrogen to balance was passed via a demand resuscitator to a rotameter and then to a metereological balloon (approximately $30 \mathrm{~L}$ capacity) that served as a target. The subject, wearing a noseclip, breathed through a low resistance twoway valve (Hans-Rudolf No. 2700; Kansas City Mo, USA). The subject was asked to ventilate for $6-8 \mathrm{~min}$ at a rate equivalent to $60 \%$ of predicted maximum voluntary ventilation $(\mathrm{MVV})$, (taken as FEV1 ×37.5) [14]. The ventilation and duration of ISH was kept the same for the three study days for the same subject.

\section{Measurement of mucociliary clearance}

Inhalation of radioaerosol. Mucociliary clearance was assessed using a radioaerosol technique. $99 \mathrm{mTc}$-sulphur colloid (Australian Radioisotopes; ANSTO, Sydney, Australia) approximately $1 \mathrm{GBq}$, was diluted in $5 \mathrm{~mL}$ of isotonic saline. The radioaerosol was generated by an Acorn nebulizer (Medic-Aid, Peckham, Sussex, UK), using oxygen from a cylinder set to $6 \mathrm{~L} \cdot \mathrm{min}^{-1}$. The droplets had a mass median aerodynamic diameter (MMAD) of $6 \mu \mathrm{m}$ and a geometric standard deviation (GSD) of 1.7 measured by a seven stage cascade impactor (DCI6; Delron, Columbus, Ohio, USA). The dilution air supplementing the flow to the mouthpiece was humidified to maintain the characteristics of the droplets [15]. The radioaerosol was delivered with a controlled breathing pattern in order to maximize deposition in the conducting ciliated airways. A closed breathing circuit was linked to an IBM computer, that allowed monitoring and control of the breathing pattern using a target volume and target inspiratory and expiratory times [16]. The target volume, set to $450 \mathrm{~mL}$, was displayed on the screen together with the target line oscillating at set rates, aiming at a peak inspiratory flow rate of $60 \mathrm{~L} \cdot \mathrm{min}^{-1}$. The inspiratory time was set higher than the expiratory time, and the subject tried to breath according to the set tidal volume and flow rates. The patient inhaled the radioaerosol for approximately $2 \mathrm{~min}$. This delivery time was chosen so that the gamma camera count rate was about 2,000 counts $\cdot \mathrm{s}^{-1}$ over the posterior thorax. Upon termination of the delivery of radioaerosol, the subjects removed the radioactivity from their oropharynx and the oesophagus by rinsing and gargling with water and expectorating, and by swallowing some bread and water.

Imaging. Lung images were obtained using a gamma camera (Phillips Diagnost Tomo; Hanburg, Germany) fitted with a low energy, all purpose, collimator and linked to an on-line computer (DEC PDP11; Maynard, MA, USA). The images were collected in a $64 \times 64$ matrix.

In order to delineate the lung fields, for regions of interest definition in the analysis, the subjects had an anterior and posterior transmission image [17], taken using a flood source containing approximately $1.5 \mathrm{GBq}$ of ${ }^{153} \mathrm{Gd}$ in water. An anterior and a posterior emission image (static), 1 min each, were collected for each subject approximately $10 \mathrm{~min}$ after the inhalation of the radioaerosol. The purpose of this image was to define the initial deposition of the radioaerosol in terms of distribution and intensity. As soon as the intervention had finished, the subject was placed in the supine position and successive anterior and posterior emission images (dynamic) of $20 \mathrm{~s}$ each were collected dynamically for $45 \mathrm{~min}$ [18]. Care was taken that the collection of the dynamic emission images started within a maximum of three min post intervention. In order to align the lung fields between the transmission, static and the dynamic images, images of markers placed on premarked positions on the subject's body were also collected at the end of each study. Care was taken that all emission images were taken at the same time after the mid-inhalation time of the radioaerosol for the 3 study days.

\section{Image and data analysis}

All the images were decay corrected to the mid-inhalation time of the radioaerosol. Geometric mean (GM) images were obtained from the anterior and posterior images for the transmission, static and dynamic emission images [18]. The left lung was not analysed as there could be possible interference from the activity in the stomach. The right lung was divided into three regions of interest: central, intermediate, peripheral [19], in order to estimate the initial deposition of the radioaerosol and subsequent clearance. An estimate of the initial homogeneity of deposition was obtained from the static emission GM image by calculating the penetration index (PI) as follows:

\section{$\mathrm{PI}=$ activity in peripheral region/activity in central region}

A bi-exponential function was fitted to the curve obtained from the dynamic GM images, using a nonlinear least squares method (PCNONLIN, SCI, Software, Lexington, KY, USA). The fitted data were extrapolated to $1 \mathrm{~min}$ post intervention, if the start of the dynamic emission images was delayed up to $3 \mathrm{~min}$. The activity of the whole right lung and the defined regions in the static emission image, measured before the intervention, was taken as the initial activity and expressed as $100 \%$ 
retention. The activity of the whole right lung and the defined regions in the dynamic emission images, measured after the intervention, was converted to counts per minute (cpm) and expressed as a percentage of the initial activity. Mucociliary clearance was the difference between the initial activity and the percentage retained at the specified time. Data from the best fit were used to calculate the \% clearance during and post intervention as follows:

$\%$ clearance $=\quad$ initial activity - activity at 1 min post intervention during intervention

initial activity

activity at $1 \mathrm{~min}$ post intervention -

activity at 45 min post intervention

$\%$ clearance $=$

activity at $1 \mathrm{~min}$ post intervention

$\times 100$

\section{Statistical analysis}

Analysis of variance (ANOVA) with repeated measures (two-factor ANOVA) was performed to compare the two groups in terms of the effect of frusemide on clearance during and post ISH. The same analysis was also carried out for the clearance rate for every $10 \mathrm{~min}$ interval post intervention. If the two groups were different, then ANOVA with repeated measures (one-factor ANOVA) was performed for each group separately.

Comparison of the deposition of radioaerosol on the two study days of both groups was made with ANOVA with repeated measures (two-factor ANOVA).

Spearman's correlation analysis was performed between the $\%$ fall in FEV1 and the difference in the clearance rate between the frusemide and the vehicle in the first $10 \mathrm{~min}$ post-ISH in the asthmatic subjects.

\section{Results}

The increase in mucociliary clearance following ISH with dry air was significantly delayed, in the presence of frusemide, in the whole right lung $(\mathrm{p}<0.002)$ and central region $(\mathrm{p}<0.01)$ of the asthmatic subjects (fig. 1) but not in the healthy subjects (fig. 2). This delay in the presence of frusemide was manifested by a significantly slower clearance rate in the first $10 \mathrm{~min}$ (figs 1 and 3 ), on average, after the ISH, although in two asthmatic subjects it persisted for 17 and $20 \mathrm{~min}$ (fig. 4). The mean $\%$ clearance $\min ^{-1}$ was 43 and $57 \%$ slower in the whole right lung and central region, respectively, in the first $10 \mathrm{~min}$ post-ISH, in the presence of frusemide compared to its vehicle, in the asthmatic subjects (fig. 1). In the asthmatic subjects, the mean difference (95\% confidence intervals) in the $\%$ clearance $\cdot \mathrm{min}^{-1}$ between frusemide and vehicle in the first $10 \mathrm{~min}$ in the whole right lung and central region was $-0.865(-1.323$ to -0.407$)$ and $-1.214(-2.074$ to -0.354$)$, respectively. This delay was observed in 9 out of 11 asthmatic subjects. For seven subjects, the delay occurred in both the whole right lung and central region, and in a further two asthmatic subjects in the central region only. By contrast, for the healthy subjects there was no significant effect of frusemide on MCC rates (figs. 2 and 5), although one subject had

\section{Asthmatic subjects}
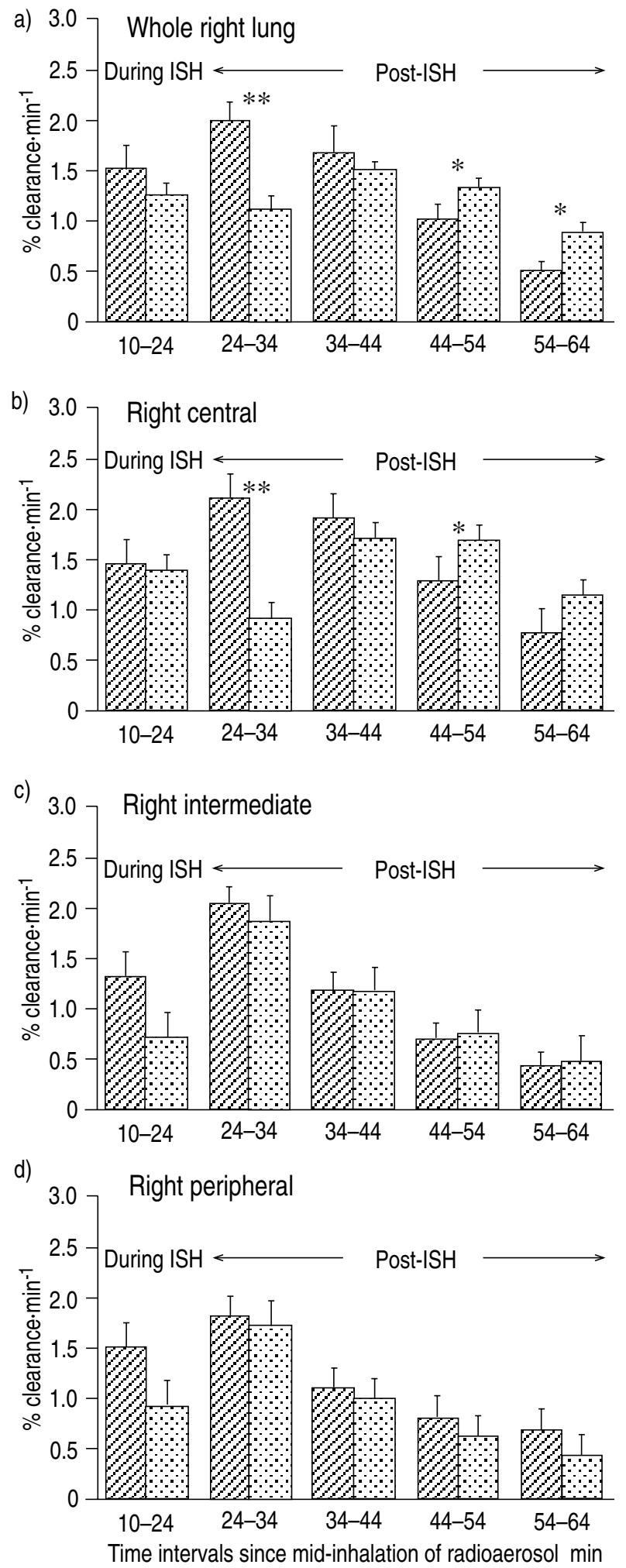

Fig. 1. - Mean \% clearance rates of: a) the whole right lung; and b) the central region; c) the right intermediate region; and d) the right peripheral region, in the presence of frusemide $\because \because$ and its vehicle $Z$ in the asthmatic subjects. Frusemide compared to its vehicle significantly delayed the increase in the mucociliary clearance rate for about $10 \mathrm{~min}$ after isocapnic hyperventialtion (ISH) with dry air in the whole right lung and central region of the asthmatic subjects. Values are presented as mean \pm SEM. *, **: $\mathrm{p}<0.05, \mathrm{p}<0.01$, respectively. 


\section{Healthy subjects}
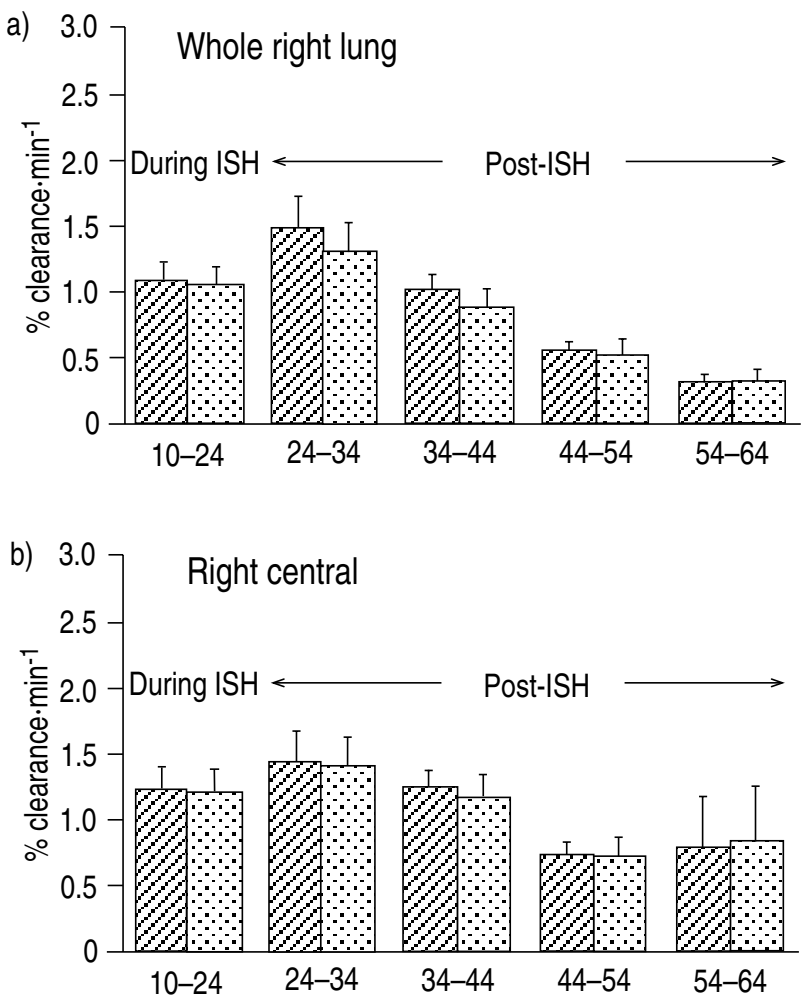

c) 3.07 Right intermediate

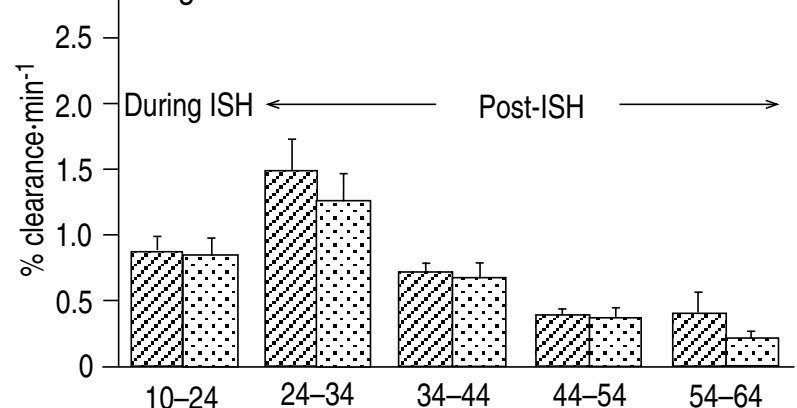

d) 3.07 Right peripheral

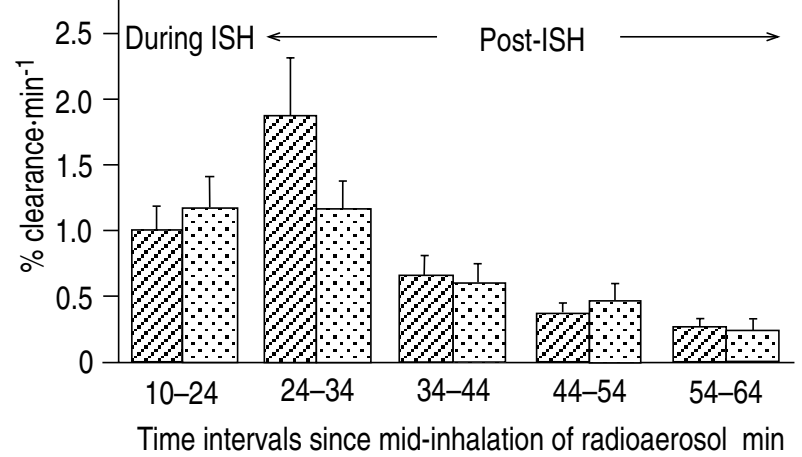

Fig. 2. - Mean \% clearance rates of: a) the whole right lung; b) the right central region; c) the right intermediate region; and d) the right peripheral region, in the presence of frusemide $\because$ and its vehicle $Q$ in the healthy subjects. Frusemide in comparison with its vehicle had no effect on the mucociliary clearance rate. Values are presented as mean \pm SEM. ISH: isocapnic hyperventilation.
Asthmatic No. 5
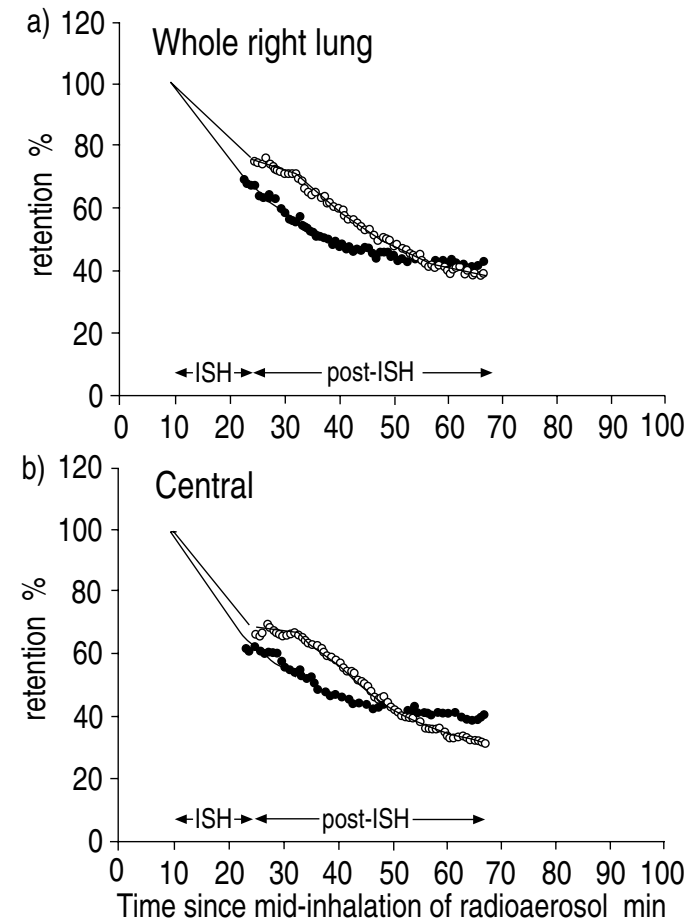

Fig. 3. - Example of mucociliary clearance (MCC) of: a) the whole right lung; and b) the central region, in the presence of frusemide and vehicle in an asthmatic subject (No. 5). This figure demonstrates the average delay in the increase of MCC rate after isocapnic hyperventilation (ISH) with dry air. $\mathbf{0}$ : vehicle; $\bigcirc$ : frusemide.

Asthmatic No. 3
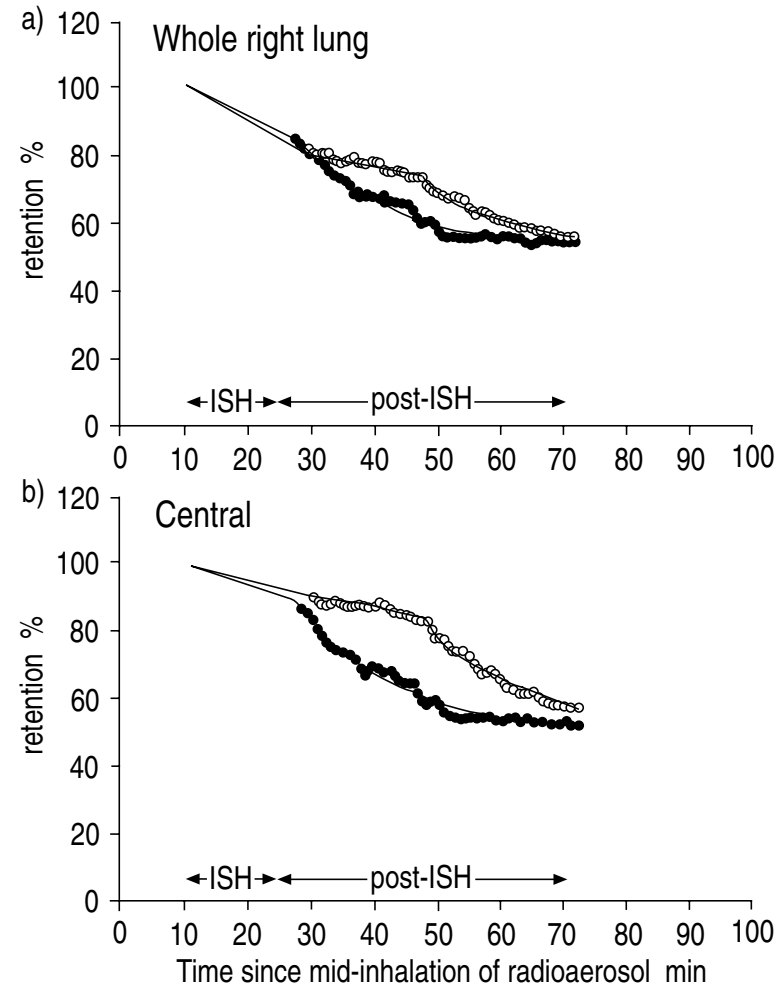

Fig. 4. - Example of mucociliary clearance (MCC) of: a) the whole right lung; and b) the central region, in the presence of frusemide and vehicle in an asthmatic subject (No. 3). This figure demonstrates a prolonged delay (about $20 \mathrm{~min}$ ) in the increase of MCC rate after ISH with dry air. ISH: isocapnic hyperventilation. 0 : vehicle; $\bigcirc$ : frusemide. 
a reduction in both the whole right lung and central region, and a further two subjects displayed similar findings to the asthmatic subjects in the central region.

Frusemide had no significant effect $(\mathrm{p}>0.3)$ on the mucociliary clearance rate during ISH in either group, although in the intermediate region the difference approached statistical significance ( $\mathrm{p}=0.08$ ) (figs. 1 and 2). After ISH, in the asthmatic subjects, there appeared to be a "catch up" period in MCC with frusemide, after the initial delay. The rate of MCC in the presence of frusemide was significantly higher compared to its vehicle $30 \mathrm{~min}(\mathrm{p}<0.02)$ after ISH (interval 44-54 min since mid-inhalation of the radioaerosol), in the whole right lung and central region of the asthmatic subjects (fig. 1). Thus, $45 \mathrm{~min}$ after ISH, the total clearance in the presence of frusemide was the same $(p>0.2)$ as for the vehicle in the whole right lung and central region of the asthmatic subjects (table 2). Frusemide, compared to its vehicle, had no significant effect in the \% clearance $\mathrm{min}^{-1}$ for each $10 \mathrm{~min}$ interval after ISH in the intermediate and peripheral region ( $>0.2)$ in either group (figs. 1 and 2). However, frusemide compared to its vehicle caused a 5 and a $7 \%$ reduction in the total clearance $45 \mathrm{~min}$ post-ISH of the peripheral region in asthmatic and healthy subjects, respectively. This small reduction of the clearance in the peripheral region reached statistical significance $(\mathrm{p}<0.03)$ (table 2), despite the lack of effect of frusemide in the $\%$ clearance $\cdot \mathrm{min}^{-1}$ either during ISH or for each $10 \mathrm{~min}$ interval after ISH.

The distribution of deposited radioaerosol was wellmatched $(\mathrm{p}>0.8)$ on both study days, as shown by the

\section{Healthy No. 17}
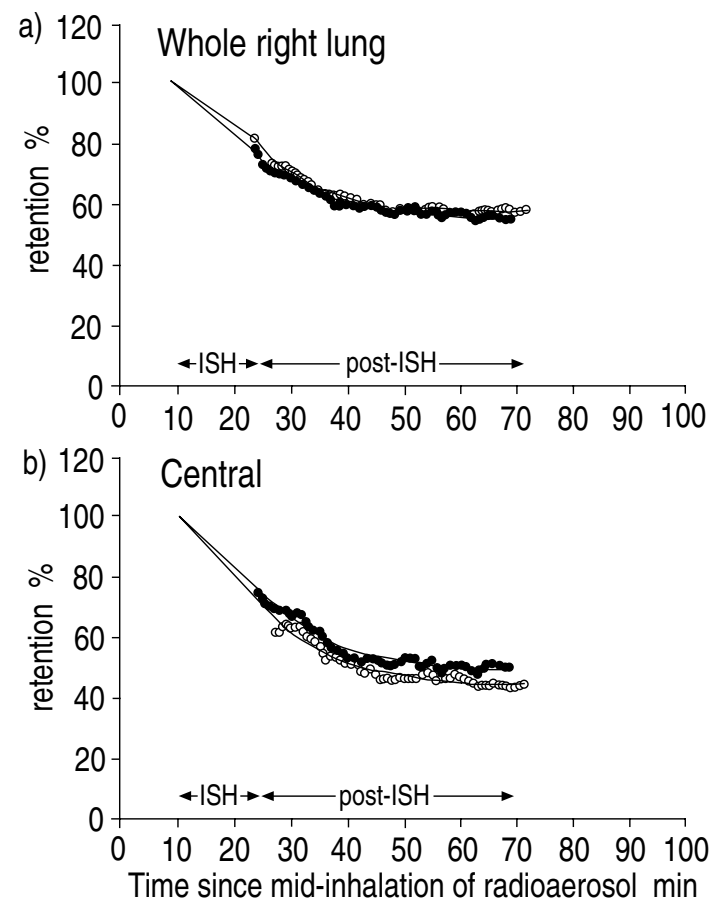

Fig. 5. - Example of mucociliary (MCC) of: a) the whole right lung; and b) the central region, in the presence of frusemide and vehicle in a healthy subject (No. 17). This figure demonstrates the lack of any effect on MCC in the presence of frusemide in the healthy subjects. ISH: isocapnic hyperventilation. $\bigcirc$ : vehicle; $\bigcirc$ : frusemide.
Table 2. - Total \% clearance during and 45 min postISH in asthmatic and healthy subjects with frusemide and vehicle

\begin{tabular}{lcccc}
\hline \multirow{2}{*}{ Region } & \multicolumn{2}{c}{ Asthmatic } & \multicolumn{2}{c}{ Healthy } \\
& Frusemide & Vehicle & Frusemide & Vehicle \\
\hline During ISH & & & & \\
Whole right lung & $18 \pm 3$ & $21 \pm 3$ & $16 \pm 2$ & $17 \pm 2$ \\
Central region & $19 \pm 4$ & $20 \pm 4$ & $18 \pm 3$ & $18 \pm 3$ \\
Intermediate region & $10 \pm 3 *$ & $18 \pm 3$ & $12 \pm 2 *$ & $13 \pm 2$ \\
Peripheral region & $14 \pm 4$ & $21 \pm 2$ & $17 \pm 4$ & $15 \pm 3$ \\
45 min-post ISH & & & & \\
Whole right lung & $42 \pm 4$ & $44 \pm 4$ & $29 \pm 4$ & $31 \pm 3$ \\
Central region & $47 \pm 4$ & $49 \pm 5$ & $33 \pm 5$ & $34 \pm 3$ \\
Intermediate region & $38 \pm 4$ & $39 \pm 4$ & $24 \pm 3$ & $27 \pm 3$ \\
Peripheral region & $33 \pm 4 * *$ & $38 \pm 5$ & $22 \pm 4 * *$ & $29 \pm 4$ \\
\hline
\end{tabular}

Values are presented as mean \pm SEM. ISH: isocapnic hyperventilation. No statistical significant differences $(p>0.3)$ between frusemide and vehicle were observed except in the peripheral region. *: $\mathrm{p}=0.08 ; * *$ : $\mathrm{p}<0.03$.

penetration indices (table 3 ), and not significantly different $(\mathrm{p}>0.8)$ between the two groups.

The airway response to ISH (\%fall in FEV1), the ventilation $\left(\mathrm{L} \cdot \mathrm{min}^{-1}\right)$ and the duration of ISH are shown in table 1 both for asthmatic and healthy subjects. Two of

Table 3. - Penetration index (PI) of the frusemide and vehicle study for asthmatic and healthy subjects

\begin{tabular}{|c|c|c|c|}
\hline No. & Vehicle & Frusemide & $\%$ change PI \\
\hline \multicolumn{4}{|c|}{ Asthmatic subjects } \\
\hline 1 & 0.208 & 0.213 & -2.4 \\
\hline 2 & 0.365 & 0.369 & -1.1 \\
\hline 3 & 0.26 & 0.321 & -23.5 \\
\hline 4 & 0.26 & 0.254 & 2.3 \\
\hline 5 & 0.139 & 0.122 & 12.2 \\
\hline 6 & 0.412 & 0.397 & 3.6 \\
\hline 7 & 0.273 & 0.267 & 2.2 \\
\hline 8 & 0.119 & 0.188 & -58.0 \\
\hline 9 & 0.408 & 0.422 & -3.4 \\
\hline 10 & 0.294 & 0.229 & 22.1 \\
\hline 11 & 0.276 & 0.27 & 2.2 \\
\hline Mean & 0.274 & 0.277 & -4.0 \\
\hline$\pm \mathrm{SD}$ & 0.096 & $\begin{array}{c}0.092 \\
p=>0.8\end{array}$ & 21.0 \\
\hline \multicolumn{4}{|c|}{ Healthy subjects } \\
\hline 12 & 0.226 & 0.215 & 4.9 \\
\hline 13 & 0.372 & 0.353 & 5.1 \\
\hline 14 & 0.237 & 0.206 & 13.1 \\
\hline 15 & 0.365 & 0.358 & 1.9 \\
\hline 16 & 0.147 & 0.197 & -34.0 \\
\hline 17 & 0.507 & 0.488 & 3.7 \\
\hline 18 & 0.352 & 0.345 & 2.0 \\
\hline 19 & 0.36 & 0.361 & -0.3 \\
\hline 20 & 0.154 & 0.177 & -14.9 \\
\hline 21 & 0.294 & 0.278 & 5.4 \\
\hline 22 & 0.18 & 0.246 & -36.7 \\
\hline Mean & 0.290 & 0.293 & -4.5 \\
\hline$\pm \mathrm{SD}$ & 0.112 & $\begin{array}{c}0.096 \\
\mathrm{p}>0.8^{\dagger}\end{array}$ & 16.6 \\
\hline
\end{tabular}

$\dagger$ : there was no significant difference between the penetration indices of frusemide and vehicle study days $(\mathrm{p}>0.8)$. 
the asthmatic subjects had a fall in FEV1 less than $10 \%$ (attributable to treatment with inhaled corticosteroids). It is of interest that the MCC of one of these two asthmatic subjects (No. 4) was not affected at all by the frusemide. However, no correlation $\left(\mathrm{p}>0.2 ; \mathrm{r}_{\mathrm{s}}=0.019\right)$ was found between the $\%$ fall in FEV1 and the difference in clearance rate between frusemide and vehicle in the first $10 \mathrm{~min}$ in the asthmatic subjects.

Frusemide had a diuretic effect immediately after hyperventilation in all subjects.

\section{Discussion}

Inhaled frusemide, an inhibitor of the $\mathrm{Na}^{+}$and $\mathrm{Cl}^{-}$cotransport systems, significantly delayed the onset of the increase in mucociliary clearance (MCC) for about 10 min after ISH with dry air in the asthmatic subjects. However, despite causing the delay in the increase in MCC, frusemide had no significant effect on the total mucociliary clearance $45 \mathrm{~min}$ after ISH when compared to its vehicle.

The delay in the onset of the increase of MCC in the presence of frusemide was observed in the whole right lung and central region in the asthmatic but not the healthy subjects. The clearance rate in the intermediate and peripheral regions was unaffected by the presence of frusemide, either during or after ISH. Therefore, the delay in the increase of clearance immediately after the ISH, in the central region and the whole right lung, did not appear to be a consequence of an increase in the clearance rate from the small airways. The delay in the onset of the increase of MCC was also of short duration, and it would have been missed if the measurements of MCC were not continuous for at least $30 \mathrm{~min}$ after ISH.

Under conditions of resting ventilation with ambient air, frusemide has no effect on MCC either in asthmatic or healthy subjects [20]. However, there is recent evidence that, under resting conditions, frusemide decreases the clearance of $99 \mathrm{mTc}$-diethylenetriomine penta-acetic acid (DTPA) in asthmatic subjects [21], suggesting that frusemide may alter the mucosal permeability in asthmatic but not in healthy subjects. In the present study, under the conditions of hyperpnoea with dry air, while frusemide did not affect the magnitude of the reduction in MCC in response to dry air, it did have an effect in delaying the increase in MCC after ISH with dry air in the asthmatic subjects. It is unlikely, however, that this effect of frusemide in the asthmatic subjects could be due to a slower clearance of frusemide from the asthmatic airways, because of the immediate diuretic effect of frusemide in the asthmatic as well as the healthy subjects. It is possible that the sensitivity to the drug may be different in asthmatic compared to healthy subjects, as has been suggested [21]

The rate of MCC can be affected if the depth of the periciliary fluid layer is not at the optimum level. Hyperventilation with dry air results in evaporative water loss from the airway surface and hyperosmolarity of the periciliary fluid layer, in agreement with experimental evidence from animal studies [22-24]. The immediate source of water of the periciliary fluid layer is the epithelial cells and the submucosa below the basement membrane. The epithelial cells initially behave like sensitive osmometers $[25,26]$. The cells shrink and the tight junctions get tighter and remain so while hyperosmolarity persists. The mechanism by which the water is restored to normality in the airway surface after hyperpnoea is not clearly understood. The results of the present study suggest that frusemide may transiently interfere with the availability of water to the airway surface of the asthmatic subjects. Water can move onto the airway surface in response to an osmotic gradient, either passively or following the transport of chloride ion. If the mechanism of water transport in response to an osmotic gradient depended largely on the chloride secretion, then its inhibition by frusemide would have affected the MCC of the healthy subjects as well. The absence of an effect of frusemide on the MCC of the healthy subjects suggests that passive diffusion of water in response to an osmotic gradient is the primary mechanism for restoring the water of the airway surface $[27,28]$ and this diffusion may be slower in asthmatic subjects [3].

We have previously found that MCC decreases during ISH with dry air [3], and we were expecting frusemide to cause an additional reduction in MCC but it did not. This suggests that inhibition of chloride secretion by frusemide had no additional effect on MCC over the effect of the dry air alone [3].

The 10 min delay in the increase in the MCC after ISH, in the presence of frusemide, in the asthmatic subjects, could relate to the time required for the epithelial cells to recover their volume and possibly to a slower rate of water diffusion. The swelling of the hypertonically shrunken cells, termed regulatory volume increase (RVI), involves an influx of $\mathrm{NaCl}$ into the cell predominantly via the activation of $\mathrm{Na}^{+} / \mathrm{K}^{+} / 2 \mathrm{Cl}^{-}$co-transport system, which is activated by the cell shrinkage and inhibited by loop diuretics, such as frusemide and bumetanide $[10,25,26]$. The RVI can take up to $20 \mathrm{~min}$ to be complete $[25,26]$. There is evidence that the apical membrane of the airway epithelium is more permeable to water than the basolateral membrane [29]. There is also evidence that asthmatic subjects have thickening of the basement membrane $[30,31]$, which could limit the rate of water diffusion when there is a high demand. It is possible that the delaying effect of frusemide in the increase of the mucociliary clearance, immediately after ISH with dry air in the asthmatic subjects, could be explained by the time needed for the epithelial cell to recover its volume after dehydration and the possible slower water diffusion due to thickness of the basement membrane.

The increase in MCC after the ISH with dry air is most likely to be due to mediators released in response to transient hyperosmolarity from epithelial cells (e.g. prostaglandin $\mathrm{E}_{2}$ ), mast cells (e.g. histamine), and sensory nerves (e.g. substance P) [32], as these mediators are known to stimulate ciliary activity and mucus transport mechanisms [33-35]. It is possible that inhibition or blocking of mediator release from mast cells [11], and neuropeptides from sensory nerves [36], by frusemide could cause a transient delay in the increase in MCC after ISH with dry air in asthmatic subjects.

In the present study, we did not measure MCC at baseline or during ISH as we have previously determined, using the same methodology as this study, that MCC decreased during ISH [3]. The values of MCC 
with vehicle or frusemide are similar to those obtained with ISH previously [3].

It is of interest that frusemide also delays rather than prevents the bronchoconstricting response to $4.5 \%$ saline aerosol [9], and ISH with dry air [7, 8]. Frusemide when inhaled prior to $4.5 \%$ saline caused a 2.6 doubling dose increase in the provocative dose causing a $20 \%$ fall in FEV1 (PD20) [9]. In addition, frusemide, inhaled prior to ISH with dry air, increased the provocative volume causing a $20 \%$ fall in FEV1 (PVE20) by 21 L [8], and in the study by GRUBBE et al. [7] a significant inhibition of the bronchoconstricting effect occurred only during the first $10 \mathrm{~min}$ post challenge. It is possible that the effect of frusemide on bronchoconstriction and on mucociliary clearance in asthmatic subjects may be due to a common mechanism.

Although frusemide delayed the onset of the increase in mucociliary clearance in the asthmatic subjects, it had no effect on the total clearance measured $45 \mathrm{~min}$ postISH either in asthmatic or healthy subjects. The fast clearance of frusemide from the airways, as evidenced by its systemic diuretic effect, may explain why its effect on the MCC in the asthmatic subjects was transient, and the absence of any effect 45 min post-ISH in either group. Rapid clearance could also explain the transient effect on bronchoconstriction [7-9].

In summary, frusemide in comparison with its vehicle caused a significant delay in the onset of the increase of mucociliary clearance after ISH with dry air in asthmatic but not healthy subjects. The present data suggest that after hyperpnoea with dry air: 1) frusemide may interfere with the availability of the water required to restore the depth of the periciliary fluid layer in asthmatic subjects; 2) frusemide may interfere with the mechanism, probably involving local chemical mediators, that stimulates MCC in asthmatic subjects. The short duration of the delaying effect is probably explained by the rapid elimination of frusemide from the airways.

Acknowledgements: The authors would like to thank the technical staff of the Department of Nuclear Medicine for their help in carrying out this research and the subjects for volunteering for the study.

\section{References}

1. Anderson SD, Schoeffel E, Follet R, Perry CP, Daviskas E, Kendall M. Sensitivity to heat and water loss at rest and during exercise in asthmatic patients. Eur J Respir Dis 1982; 63: 459-471.

2. Strauss RH, McFadden ER Jr, Ingram RH Jr, Deal EC $\mathrm{Jr}$, Jaeger JJ. Influence of heat and humidity on the airway obstruction induced by exercise in asthma. J Clin Invest 1978; 61: 433-440.

3. Daviskas E, Anderson SD, Gonda I, Chan K, Cook P, Fulton R. Changes in mucociliary clearance during and after isocapnic hyperventilation in asthmatic and healthy subjects. Eur Respir J 1995; 8: 742-751.

4. Pliss LB, Ingenito EP, Ingram RH Jr, Pichurko B. Assessment of bronchoalveolar cell and mediator response to isocapnic hyperpnoea in asthma. Am Rev Respir Dis 1990; 142: 73-78.

5. Widdicombe JH, Nathason IT, Highland E. Effects of loop diuretics on ion transport by dog tracheal epithelium. Am J Physiol 1983; 245: C388-C396.

6. Bianco S, Vaghi A, Robuschi M, Pasargiklian M. Prevention of exercise-induced bronchoconstriction by inhaled furosemide. Lancet 1988; 2(8605) July 30: 252-255.

7. Grubbe RE, Hopp R, Dave NK, Brennan B, Bewtra A, Townley R. Effect of inhaled furosemide on the bronchial response to methacholine and cold air hyperventilation challenges. J Allergy Clin Immunol 1990; 85: 881-884.

8. Rodwell LT, Anderson SD, du Toit J, Seale JP. Different effects of inhaled amiloride and frusemide on airway responsiveness to dry air challenge in asthmatic subjects. Eur Respir J 1993; 6: 855-861.

9. Rodwell LT, Anderson SD, du Toit J, Seale JP. The effect of frusemide on airway sensitivity to inhaled $4.5 \%$ sodium chloride aerosol in asthmatic subjects. Thorax 1993; 48: 208-213

10. Eveloff JL, Warnock DG. Activation of ion transport systems during cell volume regulation. Am J Physiol (Renal Fluid Electrolyte Physiol 21) 1987; 252: F1-F10.

11. Anderson SD, Wei HE, Temple DM. Inhibition by furosemide of inflammatory mediators from lung fragments. N Engl J Med 1991; 324: 131.

12. Goldman HI, Becklake MR. Respiratory function tests. Am Rev Respir Dis 1959; 79: 457-467.

13. Phillips YY, Jaeger JJ, Laube BL, Rosenthal RR. Eucapnic voluntary hyperventilation of compressed gas mixture. Am Rev Respir Dis 1985; 131: 31-35.

14. Smith CM, Anderson SD. A comparison between the airway response to isocapnic hyperventilation and hypertonic saline in subjects with asthma. Eur Respir J 1989; 2: 36-43.

15. Phipps PR, Gonda I. Droplets produced by medical nebulizers: some factors affecting their size and solute concentration. Chest 1990; 97: 1327-1332.

16. Phipps PR, Gonda I, Anderson SD. Apparatus for the control of breathing patterns during aerosol inhalation. J Aerosol Med 1992; 5: 155-170.

17. Bailey DL, Hutton BF, Walker PJ. Improved SPECT using simultaneous emission and transmission tomography. J Nucl Med 1987; 28: 844-851.

18. Bailey DL, Fulton RR, Jackson CB, Hutton BF. Dynamic geometric mean studies using a single headed rotating gamma camera. J Nucl Med 1989; 30: 1865-1869.

19. Phipps PR, Gonda I, Bailey DL, Borham P, Bautovich $\mathrm{G}$, Anderson SD. Comparisons of planar and tomographic gamma scintigraphy to measure the penetration index of inhaled aerosols. Am Rev Respir Dis 1989; 139: 1516-1523.

20. Hassani A, Pavia D, Spiteri MA, et al. Inhaled frusemide does not affect lung mucociliary clearance in healthy and asthmatic subjects. Eur Respir J 1994; 7: 1497-1500.

21. Inoue T, Shigeta M, Mochizuki H, et al. Effect of inhaled furosemide on lung clearance of technetium- ${ }^{99} \mathrm{~m}$-DTPA. J Nucl Med 1995; 36: 73-77.

22. Boucher RC, Stutts MJ, Bromberg P, Gatzy JT. Regional differences in airway surface liquid composition. J Appl Physiol: Respirat Environ Exercise Physiol 1981; 50: 613-620.

23. Man SFP, Adams GK III, Proctor DF. Effects of temperature, relative humidity, and mode of breathing on canine airway secretions. J Appl Physiol: Respirat Environ Exercise Physiol 1979: 46: 205-210.

24. Sheppard KL, Rahmoune H. Evaporation-induced changes in airway liquid on an isolated guinea pig trachea. $J$ Appl Physiol 1994; 76(3):1156-1165.

25. MacLeod RJ, Hamilton JR. Regulatory volume increase 
in mammalian jejunal villus cells is due to bumetanidesensitive $\mathrm{NaKCl}_{2}$ co-transport. Am J Physiol 1990; 258: G656-G674.

26. O'Brien JA, Walters RJ, Valverde MA, Sepulveda FV. Regulatory volume increase after hypertonicity- or vasoactive intestinal peptide-induced cell volume decrease in small intestinal crypts is dependent on $\mathrm{Na}^{+}-\mathrm{K}^{+}-2 \mathrm{Cl}^{-}$ co-transport. Pflügers Arch 1993; 423: 67-73.

27. Yankanskas JR, Gatzy JT, Boucher RC. Effects of raised osmolarity on canine tracheal ion transport function. $J$ Appl Physiol 1987; 62(6): 2241-2245.

28. Boucher RC. Human airway ion transport. Part two. Am J Respir Crit Care Med 1994; 150: 581-593.

29. Willumsen NJ, Davis CW, Boucher RC. Selective response of human airway epithelia to luminal but not serosal solution hypertonicity. J Clin Invest 1994; 94: 779-787.

30. Roche WR, Beasley R, Williams JH, Holgate ST. Subepithelial fibrosis in the bronchi of asthmatics. Lancet 1989; 1(8637) March: 520-524.

31. Jeffery RK, Godfrey RW, Adelroth E, Nelson F, Rogers A, Johansson SA. Effects of treatment on airway inflammation and thickening of basement membrane reticular collagen in asthma. Am Rev Respir Dis 1992; 145: 890-899.

32. Jongelan RC, de Jongste JC, Raatgee RC, Stijnen T, Bonta IL, Kerrebijn KF. Effect of hyperosmolarity on human isolated central airway. Br J Pharmacol 1991; 102: 931-937.

33. Wanner A, Maurer D, Abraham WM, Szepfalusi Z, Sielczak M. Effects of chemical mediators of anaphylaxis on ciliary function. J Allergy Clin Immunol 1983; 72: 663-667.

34. Garrard CS, Mussato DJ, Lourenço RV. Lung mucociliary transport in asymptomatic asthma: effects of inhaled histamine. J Lab Clin Med 1989; 113: 190-195.

35. Wong LB, Miller IF, Yeates D. Pathways of substance $\mathrm{P}$ stimulation of canine tracheal ciliary beat frequency. J Appl Physiol 1991; 70(1): 267-273.

36. Ealwood W, Lotvall JO, Barnes PJ, Chung KF. Loop diuretics inhibit cholinergic and noncholinergic nerves in guinea-pig airways. Am Rev Respir Dis 1991; 143: 13401344. 